\title{
EFFICACY OF INACTIVATED RABIES VACCINE IN HEALTHY AND IMMUNOCOMPROMISED CATS
}

\author{
SHENDY, M.B.; A.F. SOLIMAN and OMAIMA A. E.
}

Veterinary Serum and Vaccine Research Institute, Abbasia, Cairo

P.O.Box:131- Fax: (202) 23428321 svri@idsc.net.eg

(Manuscript received 23 October 2018)

\begin{abstract}
$\mathrm{P}$ ublic health studies show a protective role of rabies virus vaccine against some diseases. The use of rabies virus vaccine as an immune therapeutic modality is in light of recent findings. This work described an inadequate antibody response to feline pan leukopenia vaccine in immunocompromised cats comparing with healthy one due to an underlying immunodeficiency condition. Healthy cats were immunocompromised using immunosuppressed drug then the cats received feline pan-leukopenia vaccine. Remissions occurred following injection of many doses of inactivated rabies vaccine in immunocompromised cats. The clinical studies showed that rabies virus vaccine injections enhanced immune response in vaccination of healthy and immunocompromised cats with feline panleukopenia vaccine. It could be concluded that inactivated rabies virus vaccine can be used as an immuno-stimulant.

Key words: Rabies vaccine, immunosuppression, feline panleukopenia vaccine
\end{abstract}

\section{INTRODUCTION}

The etiological agent of rabies disease belongs to the Lyssa virus genus, Rhabdovirdae family. Rabies encephalitis remains a serious burden for public health corresponding to 1.74 million disability adjusted life years worldwide (1). Rabies virus is a neurotropic virus that causes rabies in humans and animals (2). The rabies virus has a cylindrical morphology and is enveloped with a single stranded negative sense RNA genome. The RNA genome of the virus encodes five genes encoding nucleoprotein $(N)$, phosphoprotein $(P)$, matrix protein $(M)$, glycoprotein (RVG) and the viral RNA polymerase (L) (3). Douglas $C$ Hooper (18) research group from Thomas Jefferson University reported that rabies virus vaccine significantly prolonged the survival of mice bearing intracranial GL 261 glial tumors. The extended survival was associated with delayed tumor growth and an increase of $T$ and $B$ cell markers and $\operatorname{IFN}_{\mathrm{Y}}$ (4).

Feline pan leukopenia virus (FPV), also known as feline infectious enteritis, feline distemper, is a viral infection affecting cats, both domestic and wild feline species. It is caused by feline parvovirus, a close relative of both types 2 canine parvoviruses. It is highly contagious and can be fatal to the affected cat. FPV is extremely resistant to inactivation and can survive for longer than one year in a suitable environment (5). It 
causes a decrease in the cat's white blood cells, thus compromising its immune system. Pan leukopenia is primarily spread through contact with an infected animal's body fluids, feces, or other fomites, as well as by fleas (6). The severe leukocytopenia predispose cats to secondary infections, especially bacterial and fungal, though secondary viral infections also occur with some frequency. Cats of all ages are susceptible to infection. The incubation period is approximately 5 days (range 2-7 days) (7). Most pan leukopenia deaths are due to secondary infections or dehydration resulting from diarrhea. This is because the virus affects the infected cat's immune system. Feline pan leukopenia and canine parvovirus are extremely closely related, but viruses cannot be transmitted between dogs and cats. The early studies in combination with contemporary findings about immune responses against rabies virus to discuss whether rabies virus vaccine may be beneficial as an adjuvant treatment in immunocompromised cats with feline pan-leukopenia. To elucidate whether rabies virus vaccine is safe in immunocompromised cats, many strategies have been explored in immunocompromised animals in order to optimize vaccination outcomes, including increased dosage, multiple dose vaccination and the use of vaccine adjuvant, immuno-stimulant patches and more efficient routes of vaccine delivery. All vaccinations should preferably be administered before initiating or intensifying immunosuppressive therapy.

The aim of current study is to investigate specific and non-specific immunostimulation by rabies virus vaccine as immuno-stimulant for immunocompromised cats.

\section{MATERIALS AND METHODS}

\section{Rabies vaccine:}

Inactivated rabies virus vaccine (ERA strain) was supplied by the Department of Pet Animal Vaccine Research (DPAVR); Veterinary Serum and Vaccine Research Institute (VSVRI). It was used as immuno-stimulant agent.

\section{Feline pan-leukopenia vaccine:}

It was supplied by DPAVR and used for vaccination of cats.

\section{Glucocorticoid (Solu-Cortef ${ }^{\circledR}$ ):}

It was supplied as $100 \mathrm{mg}$ powder; one vial contains as active agent hydrocortisone sodium succinate proceed by Pfizer Company. It was administered by $\mathrm{I} / \mathrm{M}$ route at a dosage of $50 \mathrm{mg} / \mathrm{kg}$ body weight, every 72 hours for 2-3 weeks. It was used as immunosuppressed.

\section{Cats:}

Twelve native breed kettles of about 4-6 months of age were used in the present study and proved to be seronegative to Feline pan-leukopenia antibodies as screened 
by serum neutralization test (SNT). They were apparently healthy free from external and internal parasites and housed under the hygienic measures in separate kennels receiving balanced diet and adequate water.

\section{Experimental design:}

The cats were divided into four groups (3cats/group) and immunized subcutaneously with a dose of $2 \mathrm{ml}$ for both vaccines, where the rabies virus vaccine injected for 7 days and allocated as follow:

Group-1: Healthy cats received feline pan-leukopenia vaccine and seven injections of inactivated rabies virus vaccine simultaneously.

Group-2: Immunosuppressed cats received feline pan-leukopenia vaccine and seven injections of inactivated rabies virus vaccine. simultaneously

Group-3: Immunosuppressed cats received feline pan-leukopenia vaccine only.

Group-4: Healthy cats non vaccinated and non-treated were kept as control.

Blood samples were collected from all cat groups after injection and vaccination immediately and then weekly till 16 weeks. The blood samples were divided into whole blood with anticoagulant (EDTA) for whole blood picture and serum which was stored at $-20^{\circ} \mathrm{C}$ till subjected to serological examination.

\section{Complete Blood Picture:}

The purpose of this study was given as a general overview of Complete Blood Count (CBC). Simplified table $\{2\}$ is provided with the most common values included on this test.

\section{Rabies Vaccine ( $R V$ ) protocol:}

The cats received seven injections of inactivated rabies virus vaccine according to rabies virus injection protocol (8). Consecutive daily injections of RV were given for 7 days subcutaneously.

\section{Serum neutralization test (SNT):}

It was carried out (9) and used to screen cats to feline pan-leukopenia antibodies just prior and post vaccination. 
RESULTS AND DISCUSSION

Table 1. Complete Blood Count of healthy and immuno-compromised cats:

\begin{tabular}{|c|c|c|c|c|c|c|}
\hline \multirow{2}{*}{ Parameters } & \multicolumn{4}{|c|}{ Values } & \multirow{2}{*}{$\begin{array}{l}\text { References } \\
\text { Range }\end{array}$} & \multirow{2}{*}{ Comment } \\
\hline & Gr.1 & Gr.2 & Gr.3 & Gr.4 & & \\
\hline Plasma protein $(\mathrm{g} / \mathrm{dl})$ & 7 & 6 & 3 & 6 & $6-8$ & dehydration \\
\hline $\mathrm{Hb}$ (Hemoglobin) (g/dl) & 12 & 9 & 6 & 10 & $8-15$ & hemolysis \\
\hline $\begin{array}{l}\text { RBC(Red blood } \\
\text { cell }\left(10^{12} / \mathrm{L}\right)\end{array}$ & 9 & 6 & 4 & 8 & $5-10$ & Anemia \\
\hline $\begin{array}{l}\text { WBC(white blood } \\
\text { cells }\left(10^{2} / \mathrm{L}\right)\end{array}$ & 15 & 4 & 1 & 9 & $5-20$ & Infection \\
\hline Bands & 200 & 3 & 0 & 180 & $0-300$ & Acute infection \\
\hline Segmented neutrophils & 10 & 2 & 5 & 7500 & $2500-12.500$ & Infection \\
\hline Lymphocytes & 5.000 & 1.250 & 7.00 & 4.000 & $1.500-7.000 / L$ & $\begin{array}{l}\text { Chronic } \\
\text { infection }\end{array}$ \\
\hline Monocytes & 500 & 200 & 0 & 400 & $0-800 / L$ & Macrophages \\
\hline Eosinophil's & 100 & 220 & 0 & 500 & $0-700 / L$ & Infection \\
\hline Basophils & Rare & high & high & Rare & Rare & $\begin{array}{l}\text { Parasitic } \\
\text { infestation }\end{array}$ \\
\hline
\end{tabular}

Gr.1: Healthy cats received feline pan-leukopenia vaccine and inactivated rabies vaccine simultaneously

Gr.2: Immunosuppressed cats received feline pan-leukopenia vaccine and inactivated rabies vaccine Simultaneously

Gr.3: Immunosuppressed cats received feline pan-leukopenia vaccine only

Gr.4: Healthy cats did not receive any substances as control.

Table 2. Mean titers of feline pan-leukopenia serum neutralizing antibodies in sera of healthy and immunosuppressed cats

\begin{tabular}{|c|c|c|c|c|c|c|c|}
\hline \multirow{2}{*}{$\begin{array}{c}\text { Animal } \\
\text { Groups }\end{array}$} & \multicolumn{6}{|c|}{ Mean feline pan-leukopenia serum neutralizing antibody titer* /weeks post-vaccination } \\
\cline { 2 - 8 } & OWPV^ & 1 WPV & 2WPV & 4 WPV & 8 WPV & 12 WPV & 16 WPV \\
\hline 1 & 0.00 & 4 & 16 & 32 & 64 & 128 & 128 \\
\hline 2 & 0.00 & 4 & 8 & 8 & 16 & 32 & 32 \\
\hline 3 & 0.00 & 4 & 4 & 4 & 8 & 16 & 16 \\
\hline 4 & 0.00 & 0.00 & 0.00 & 0.00 & 0.00 & 0.00 & 0.00 \\
\hline
\end{tabular}

*Antibody titer = the reciprocal of the final serum dilution which neutralized and inhibited the CPE of 100 $\mathrm{TCID}_{50}$ of feline pan-leukopenia virus.

$\mathrm{WPV}^{\wedge}=$ Week Post Vaccination.

Group-1: Healthy cats received feline pan-leukopenia vaccine and inactivated rabies vaccine simultaneously,

Group-2: Immunosuppressed cats received feline pan-leukopenia vaccine and inactivated rabies vaccine simultaneously,

Group-3: Immunosuppressed cats received feline pan-leukopenia vaccine only.

Group-4: Healthy cats did not receive any substances as control.

NB: The protective level of feline pan-leukopenia antibody titer is not less than 32.

The development of vaccines is one of the greatest achievements in the history of medicine. Vaccine adjuvants are widely used to accelerate and boost immune response. Therefore, it is likely that rabies virus surface molecules triggered a general stimulation of lymphocyte reactivity diseased cats with already augmented immune responses. Rabies virus glycoproteins (RVG) induce both humoral and cellular immune responses (10). These studies may also pave way to develop novel anticancer vaccines with fewer side effects than the native rabies virus vaccine. 
Complete blood count $(\mathrm{CBC})$ values are listed in Table (1). Total protein on a $\mathrm{CBC}$ is slightly different from that of the profile because it is run on plasma, while the protein measurements on a profile is run on serum, but are otherwise similar. $\mathrm{Hb}$ (hemoglobin) and RBC provide information regarding the size and content of RBC's, which can tell something about the production process of RBC's from the bone marrow and the process of loss in the case of anemia. White blood cells (WBCs) generally indicate inflammation or infection somewhere in the body when they are elevated. A diseased cat under chronic stress has increased glucocorticoid release, which leads to a decrease in lymphocytes and an increase in neutrophils and monocytes. The prognosis of feline pan-leukopenia is grave if the white blood cell count falls below 1000 cells per $\mathrm{mL}$ of blood (11). If an immune response to rabies develops either inappropriately or after the infection has spread sufficiently, an extensive immune-mediated damage could be expected (12). Cells of the immune systems may share similar functions: secretion of immuno-regulatory cytokines, response to cytokines, and antigen presentation.

In Table (2) estimation of humoral immune response of vaccinated animals by serum neutralization test (SNT) revealed that vaccinated healthy animals acquired feline pan-leukopenia antibodies with high protective level (128) by using inactivated rabies vaccine as immuno-stimulant as in (group-1), but vaccinated immunocompromised cats with both feline pan-leukopenia and rabies vaccines produce low protective level (32) of virus neutralizing antibodies as in (group-2). On the other hand, the vaccinated immunocompromised cats with feline pan-leukopenia vaccine produced antibody titer that was lower (16) than the protective level of feline pan-leukopenia titer (32) as in (group-3). Thus, this is in agreement with Kopel (20) who reported that diseased animals have an advanced B cell lymphoma failed to develop antibodies following rabies virus vaccine application. Besides, in 2011, Hooper (18) research group reported that rabies virus vaccine significantly prolonged the survival of mice bearing intracranial glial tumors. The extended survival was associated with delayed tumor growth and an increase of $\mathrm{T}$ and $\mathrm{B}$ cell markers and $\operatorname{IFN}_{Y}$ (13). The rabies vaccines initiate a T-cell-independent immune response, although partial and non-specific dependency of T-cells has been described for some of the antigens included in the vaccine. In this regard, it is plausible to argue that rabies virus vaccine might have stimulated a broader immune response against cancer growth (14). Therefore; it is likely that rabies virus surface molecules triggered a general stimulation of lymphocytes reactivity in cats with already augmented immune responses. Therefore, believed that rabies virus vaccine may be safety applied to cancer cats.

The results of the present study illustrated that rabies vaccine inoculated with feline pan-leukopenia vaccine simultaneously produced a protective level after 12 
weeks. The unique rabies virus glycoprotein (RVG) is organized in trimers that protrude from the viral envelope and a single type I glycoprotein $\mathrm{G}$ of $65 \mathrm{kDa}$ inserted in virus membrane, is responsible for both the binding of the virus to the target cells and the fusion between virus and cell membranes (15\&16).

During the clearance of an infection with attenuated rabies virus, blood brain barrier (BBB), however, allows $T$ and B lymphocyte entry into CNS tissues without involvement of the neutrophils and monocytes responsible for inflammatory pathological changes (17). Factors which contribute to the RV-specific CNS immunity include chemokine's and the important cytokine, TNF. Therefore, injecting with rabies virus vaccine at regular intervals for therapeutic purpose may be expected to cause stronger immunity than the native infection (18). Presence of phosphatidylinositol (PI) on the rabies virus surface and its strong recognition in cancer patients may indicate that lipids of rabies virus may exert a general immuno-stimulation not limited to the glioblastoma, melanoma, and cervical cancer (19). RVG is the main viral antigen and the target of neutralizing antibodies. RVG induces both humoral and cellular immune responses. Intradermal (ID) application of RV-V induces $\mathrm{T}$ helper-2 responses and elevation of eotaxin, a chemokine with a major role in allergic responses (20).

It was concluded that the inactivated rabies virus vaccine can be used as immuno-stimulant.

\section{REFERENCES}

1. Houimel M and Dellagi K. 2009. Peptide mimotopes of rabies virus glycoprotein. Immunogenic activity. Vaccine, 27(34):4648-55.

2. Carter J and Saunders VA. 2007. Virology: principles and application. Chi Chester: Wiley, p 175.

3. Tinke $S$ and Conzelmann KK. 2005. Replication strategies of rabies virus. Virus Res. 111 (2): 120-31.

4. Bongiorno E, Morin-Brureau M, Barkhouse D, Faber M, Dietzschold B and Hooper D. 2013. A novel rabies virus-based glioma immunotherapeutic strategy targeting survives (P4440). J Immunol. 190 (1 supplement): 126-5.

5. "Feline Panleukopenia: Introduction". Whitehouse Station, NJ USA: Merck Sharp \& Dohme Corp., a subsidiary of Merck \& Co., Inc. Retrieved 26 May 2011.

6. "Feline Panleukopenia (feline enteritis) in Cats- Causes, Symptoms \& Treatment". Retrieved 26 May 2011.

7. In Fenner's Veterinary Virology (Fifth Edition), 2017.

8. Pack GT. 1950. Note on the experimental use of rabies vaccine for melaonmtosis. AMA Arch Derm Syphilol. 62(5):694-5.

9. Rossiter, P.B.; Jessett,D.M. and Taylor,W.P. 1985. Microneutralization system for use with different strains of peste des petits ruminant's virus. Top. Anim. Hith. Prod., 17(2): 75-81. 
10. Dietzschold B., Schenell M. and Koprowski H. 2005. Pathogenesis of rabies. Curr. Top. Microbiol Immunol., 292:45-56.

11. Xlang ZQ. Knowless BB. Mccarick JWand Erthrth HC. 1995. Immune effectors mechanisms required for protection to rabies virus. Virology, 214, 398-404.

12. Fabet M., Pulmanausahakul R. and Hodawadekar SS., Spitsin S., Mcgettigan JP., Schnell MJand Dietzschold B. 2002. Over expression of the rabies virus glycoprotein results in enhancement of apoptosis and antiviral immune response. J. Virol., 76, 3374-81.

13. Prehaud C., Lay S., Dietzschold B and Lafon M. 2003. Glycoprotein of nonpathogenic rabies viruses is a key determinant of human cell apoptosis. J. Virol. 77, 10537- 47.

14. Iwasaki Y., Gerhad W. and ClarkHF. 1997. Role of host immune response in the development of either encephalitic or paralytic disease after experimental rabies infection in mice. Infect. Immun., 18, 220-5

15.Tuffereau C, Be'ne'jean J, Blondel D, Kieffer B and Flamand A. 1995. Low-affinity nerve growth factor receptor (P75NTR) can serve as a receptor for rabies virus. EMBO J.; 17(24):7250-9.

16. Langevin C, Jaaro H, Bressanelli S, Fainzilber M and Tuffereau C. 2002. Rabies virus glycoprotein (RVG) is a trimeric ligand for the $\mathrm{N}$-terminal cysteine-rich domain of the mammalian p75 neurotrophin receptor. J Biol Chem. 277(40):37655-62

17. Lebrun A, Portocarrero C, Kean RB, Barkhouse DA, Faber M and Hooper DC . 2015. T-bet is required for the Rapid Clearance of Attenuated Rabies Virus from Central Nervous System Tissue. J. Immunol. 195(9):4358-68.

18. Hooper DC, Roy A, Kean RB, Phares TW and Barkhouse DA. 2011. Therapeutic immune clearance of rabies virus from the CNS. Future Virol. , 6(3):387-97.

19. Faiderbe S, Chagnaud JL , Wafflart Jand Geffard Ma. 1989. Autoantibodies directed against membrane phospholipid in serum in patients with malignant tumors. C R Acad Sci III. 310(3):49-52.

20. Kopel E, Oren G, Sidi $Y$ and David D. 2012. Inadequate antibody response to rabies vaccine in immunocompromised patient. Emerg Infect Dis., 18(9):1493-5. 


\section{كفاءة لقاح السعار المثبط في القطط السليمة و المثبطة مناعيا}

محمد بريك شندى ،أكرم فؤاد سليمان اميمة عطا الكريم

معهز بحوث الامصال و اللقاحات البيطرية ، العباسبة ، القاهرة

تتشير در اسات الصحة العامة بان لقاح السعار له دور وقائي ضد بعض الأمر اض ومن هـــا

المنطلق تم استخدام لقاح السعار كمحفز مناعي.وفي اطار هذا العمل نصف استجابة الأجسام المضادة

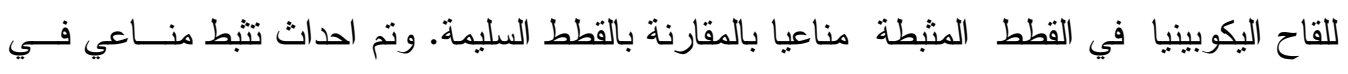

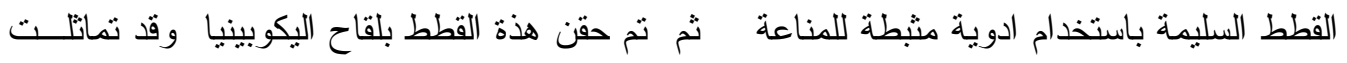

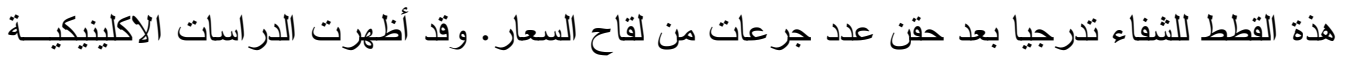

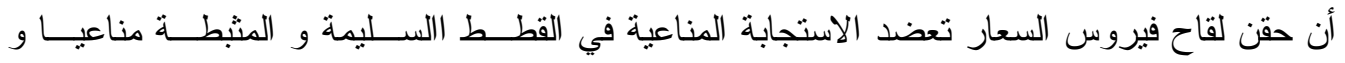

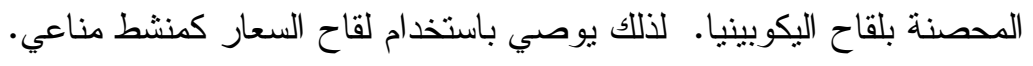

